\section{Australian Journal of \\ Crop Science}

\title{
Physical soil attributes of Conilon coffee (Coffea canephora) under organic and conventional management systems
}

\author{
Fábio Luiz Partelli ${ }^{*}$, Romano Roberto Valicheski ${ }^{2}$, Henrique Duarte Vieira ${ }^{3}$, Ivoney Gontijo ${ }^{1}$, \\ Enderson Petrônio de Brito Ferreira ${ }^{4}$
}

${ }^{1}$ Universidade Federal do Espírito Santo, Centro Universitário Norte do Espírito Santo, Rodovia BR 101 Norte, Km. 60, Bairro Litorâneo, CEP 29932-540, São Mateus, ES, Brazil

${ }^{2}$ Escola Agrotécnica Federal de Rio do Sul, Rio do Sul, SC, Brazil

${ }^{3}$ Universidade Estadual do Norte Fluminense Darcy Ribeiro, Centro de Ciências e Tecnologias Agropecuárias, Campos dos Goytacazes, RJ, Brazil

${ }^{4}$ Embrapa Arroz e Feijão, Santo Antônio de Goiás, GO, Brazil

*Corresponding author: partelli@yahoo.com.br

\begin{abstract}
Coffea sp. is cultivated in large areas, using both conventional and organic management. However, information about the sustainability of these two management systems is still deficient. The objective of the present study was to evaluate the physical properties of soil cultivated with Conilon coffee $(C$. canephora) under organic and conventional management. Two areas cultivated with Conilon coffee (under organic and conventional management) and a fragment of Atlantic forest, used as a reference, were selected for the experiment. Soil granulometry, hydraulic conductivity, water retention curve, resistance to penetration, porosity, optimal hydric interval, and other physical characteristics were measured at depths of 0 to 10 and 10 to $20 \mathrm{~cm}$. The data was submitted to multivariate and descriptive statistical analyses. Higher similarity was observed between the soil cultivated with Conilon coffee under organic management and the Atlantic forest soil. Soil resistance to penetration at 10, 30, 100, 500 and $1500 \mathrm{kPa}$, macro porosity, density and total porosity were the main physical properties that differentiated both management systems studied. The nonuse of agricultural machinery and the addition of organic matter may be the main reasons for higher soil sustainability observed under organic management when compared with the conventional system.
\end{abstract}

Keywords: Coffea canephora; sustainable coffee; resistance to penetration; optimal hydric interval; water retention curve. Abbreviations: CNPq_Conselho Nacional de Desenvolvimento Científico e Tecnológico; OHI_optimal hydric interval; RP_ resistance to penetration; $\mathrm{K}_{\mathrm{s} \_}$saturated soil; TP_total porosity; UENF_Universidade Estadual do Norte Fluminense Darcy Ribeiro; UFES_Universidade Federal do Espírito Santo; WA_water availability.

Introduction

Agronomy has greatly progressed with the use of conventional agriculture, namely in terms of knowledge and short-term productivity. However, the excessive use of conventional agricultural systems has resulted in soil and environmental degradation (Oliveira et al., 2003; Carneiro et al., 2004). In addition, conventional agriculture requires higher consumption of fossil fuels, especially because of high fertiliser and pesticide use, which contributes to the greenhouse effect through increased release of $\mathrm{CO}_{2}$ into the atmosphere (Castellini et al., 2006). These negative consequences threaten the survival of this development model. A more sustainable method of agriculture, that includes adoption of conservational practices, represents a feasible alternative for minimisation of such problems. In Brazil, most of the Coffea sp. is cultivated on conventional systems of production. However, in recent years, organic farming has emerged and is creating a new niche market for organic products. Organic agricultural products generally show greater prices and are safer for consumers than conventional products. However, there are limitations on organic production, such as the difficulty of obtaining certification for organic farmers, the lack of professional assistance, lack of research data on organic coffee cultivation, and difficulties replacing chemical fertilizers (Partelli et al. 2006). Most coffee growing areas in Brazil use conventional management. However, organic management has recently emerged as a new, particular, market niche for special coffees. Organic coffee production may be favoured by the existence of a market willing to pay more for the differentiated and fair trade products. However, it has its limitations, as for example the cost of certification, lack of specialized professionals and specific research, besides difficulties in replacing chemical fertilisation and achieving better prices. Because soil's physical properties are influenced by the management system adopted, information of the soil properties are important for optimisation and success of any agricultural activity (Araujo-Junior et al., 2011; Cortez et al., 2014; Iori et al., 2014; Sousa Neto et al., 2014). Changes in soil physical properties may influence pore volume and geometry, mechanical resistance, and the storage 
and movement of water, gases and heat of the soil and may therefore affect root and plant development (Secco et al., 2009; Oliveira et al., 2012; Fagundes et al., 2014). Letey (1985) suggested the establishment of a soil moisture range adequate for plant growth, which would be limited by values of the minimum aeration porosity and maximum mechanical resistance to root growth. Although the critical values for these properties depend on the soil and crop, a 10\% minimum aeration porosity yields oxygen diffusion that is enough for root demands and soil resistance to penetration (RP) greater than $4 \mathrm{MPa}$ is considered sufficient to prevent root growth (Unger and Kaspar, 1994). Studies have been performed for the establishment of this range of soil moisture that has been denominated "optimal hydric interval" (Silva et al., 1994; Petean et al., 2011; Torres et al., 2014). Plant root characteristics vary with the plant species, variety and age; planting density; pest or disease occurrences; soil texture and structure; and other factors. Knowledge of the soil physical properties is therefore very important because they directly and indirectly influence root development, especially at depth, which then influences plant productivity and tolerance to water deficits or other stresses in Coffea (Petean et al., 2011; Partelli et al., 2014; Torres et al., 2014).An interdisciplinary knowledge that allows integration of the different components of agricultural systems (soil, plant, and environment) is important for a better understanding of the factors related to organic and conventional coffee management and productivity. The objective of the present study was to evaluate the physical properties of soils cultivated with Conilon coffee (C. canephora) under organic and conventional management.

\section{Results and Discussion}

\section{Soil granulometry}

Soil granulometry was similar for the different studied areas and soil layers. Soils showed a light sandy loam texture (Table 1). This result indicates that the main physical differences observed among soils were due to other factors. However, organic matter concentration was higher in the forest soil, followed by the organic the soil under and finally conventional coffee cultivation soil $(228 \%$ and $137 \%$, respectively). This difference was due to the constant renovation of plant debris (for the Atlantic forest) and periodic addition of organic inputs in those two areas.

\section{Soil resistance to penetration and soil compaction}

Soil resistance to penetration (RP) at 10, 30, 100, 500 and $1500 \mathrm{kPa}$, macro porosity, density and TP were the main physical properties that differentiated both management systems studied. This result is partially in agreement with Reichert et al. (2009), who concluded that RP was the property that best characterised and differentiated different management systems and soil layers. Based on these properties, together with other soil properties tested, the systems studied were grouped into three groups using the nearest-neighbour method (Fig. 2). Both conventional coffee management soil layers $\left(0-10\right.$ and $10-20 \mathrm{~cm}$, labelled $\mathrm{n}^{\circ} 1$ and 2) formed a group, and both layers of organic coffee management and layer $10-20 \mathrm{~cm}$ of the Atlantic forest fragment formed another group (these layers were labelled $\mathrm{n}^{\circ}$ 3,4 , and 6). The classification indicates divergence between the two groups and similarity among soils within the same group. This result is in agreement with that of Partelli et al.
(2012), who analysed microbiological and chemical soil properties from the same areas studied in the present work. The third group $\left(\mathrm{n}^{\circ} 5\right)$ was constituted by the forest layer, 0 $10 \mathrm{~cm}$ depth (Fig. 2). While studying soil microbiological properties Evangelista et al. (2013) had also found higher similarities among soils from native Cerrado and organic sugar cane plantation than from a conventional plantation soil. The results of the present study, together with those obtained by Partelli et al. (2012) for soil chemical and microbiological properties, indicate some differences between organic and conventional coffee management and higher soil similarity between organic management and Atlantic forest soil. However, practically no differences were observed for some of the properties studied. This result is in agreement with Costa et al. (2006), who compared conventional cultivation and direct planting.

The soil under conventional management was evidently more compacted than that under organic management at the different soil moistures tested (Fig. 2). At higher pressure, which results in lower soil moisture, root growth may be limited since soil resistance greater than $4 \mathrm{MPa}$ impedes root growth (Unger and Kaspar, 1994). If this was the case, coffee plants would present serious growth limitations in the studied soil layers under moderate water deficits once the higher root concentration (length and surface area per soil volume) of coffee plants originated either from seeds or cuttings, were found at the soil surface layer, approximately $40 \%$ at $0-10$ $\mathrm{cm}$ and $60 \%$ at $0-20 \mathrm{~cm}$, with the remaining roots being located at deeper layers (Partelli et al., 2014). Different soil RP behaviours were observed at the different soil depths tested. At $0-10 \mathrm{~cm}$, the best fit for the RP response to the increase of pressure applied to soil for water extraction was obtained for linear models, thus demonstrating the influence of soil pressure on RP. A more pronounced linear slope was observed for coffee under conventional management, which exhibited greater RP values for drier soil. Organic management was more conservationist, showing smaller RP increases for drier soil, and exhibited behaviour similar to that of the Atlantic forest soil. All correlations were significant, with $\mathrm{R}^{2}$ values between 0.941 and 0.967 . At 10 $20 \mathrm{~cm}$, this behaviour was not clear, and the linear correlations were not significant (Fig. 2). As observed by Reichert et al., 2009, compaction had not affect negatively corn and bean roots at high soil moisture values. This indicates that at $10 \mathrm{kPa}$, the soil RP was not detrimental to coffee development, even under conventional management. On the other hand, root growth may be limited under conditions of water stress because pressure values greater than $10 \mathrm{MPa}$ were reached (Fig. 2). Lima et al. (2010) reported 1.7 and $1.9 \mathrm{MPa}$ to be critical to growth and grain productivity of bean and soybean, respectively. Secco et al. (2009) studied dystrophic red oxisol, and observed that 2.7 to 3.2 $\mathrm{MPa}$ compaction at $7-12 \mathrm{~cm}$ can decrease wheat productivity when compared with compaction of 1.7 to 2.2 $\mathrm{MPa}\left(1.87 \mathrm{Mg} \mathrm{ha}^{-1}\right.$ and $2.29 \mathrm{Mg} \mathrm{ha}^{-1}$, respectively). However, the compaction did not influence corn or soybean productivity. Muñoz et al. (2007) reported that corn crop direct planting resulted in a pronounced decrease of RP during the first and second years for layers at depths of $0-5$ $\mathrm{cm}$ and $5-10 \mathrm{~cm}$, whereas there were no differences with conventional cultivation. Higher levels of compaction caused by a higher number of tractor runs decreased soybean development and productivity (Oliveira et al., 2012), and negative correlations between compaction and dry mass of sugarcane roots and shoot development were reported (Fagundes et al., 2014). Similar effects may have occurred in 
Table 1. Granulometry and organic matter of soil under conventional and organic coffee cultivation systems and an Atlantic forest fragment at two soil depths. Jaguaré, Espírito Santo, Brazil.

\begin{tabular}{lcccccc}
\hline Area & $\begin{array}{c}\text { Depth } \\
(\mathrm{cm})\end{array}$ & Coarse sand & $\begin{array}{c}\text { Fine sand } \\
\left(\mathrm{g} \mathrm{kg}^{-1}\right)\end{array}$ & Silt & Clay & $\begin{array}{c}\text { Organic matter } \\
\left(\mathrm{dag} \mathrm{kg}^{-1}\right)\end{array}$ \\
\hline $\mathrm{CC}$ & $0-10$ & 447 & 218 & 45 & 290 & 1.27 \\
$\mathrm{SE}$ & & 10.3 & 6.3 & 8.7 & 0.0 & 0.16 \\
$\mathrm{CC}$ & $10-20$ & 447 & 205 & 53 & 295 & 0.89 \\
SE & & 16.5 & 2.9 & 11.8 & 9.6 & 0.16 \\
\hline $\mathrm{CO}$ & $0-10$ & 402 & 215 & 128 & 255 & 1.74 \\
$\mathrm{SE}$ & & 20.2 & 2.9 & 11.1 & 17.1 & 0.17 \\
$\mathrm{CO}$ & $10-20$ & 398 & 212 & 120 & 270 & 1.41 \\
SE & & 17.5 & 2.5 & 9.1 & 17.3 & 0.18 \\
$\mathrm{AF}$ & $0-10$ & 517 & 218 & 53 & 212 & 2.89 \\
$\mathrm{SE}$ & & 18.9 & 7.5 & 6.3 & 10.3 & 0.47 \\
$\mathrm{AF}$ & $10-20$ & 465 & 215 & 70 & 250 & 1.41 \\
$\mathrm{SE}$ & & 6.4 & 8.7 & 4.1 & 122 & 0.18 \\
\hline
\end{tabular}

CC -conventional conilon coffee, OC -organic conilon coffee, AF - Atlantic forest, SE - standard error.
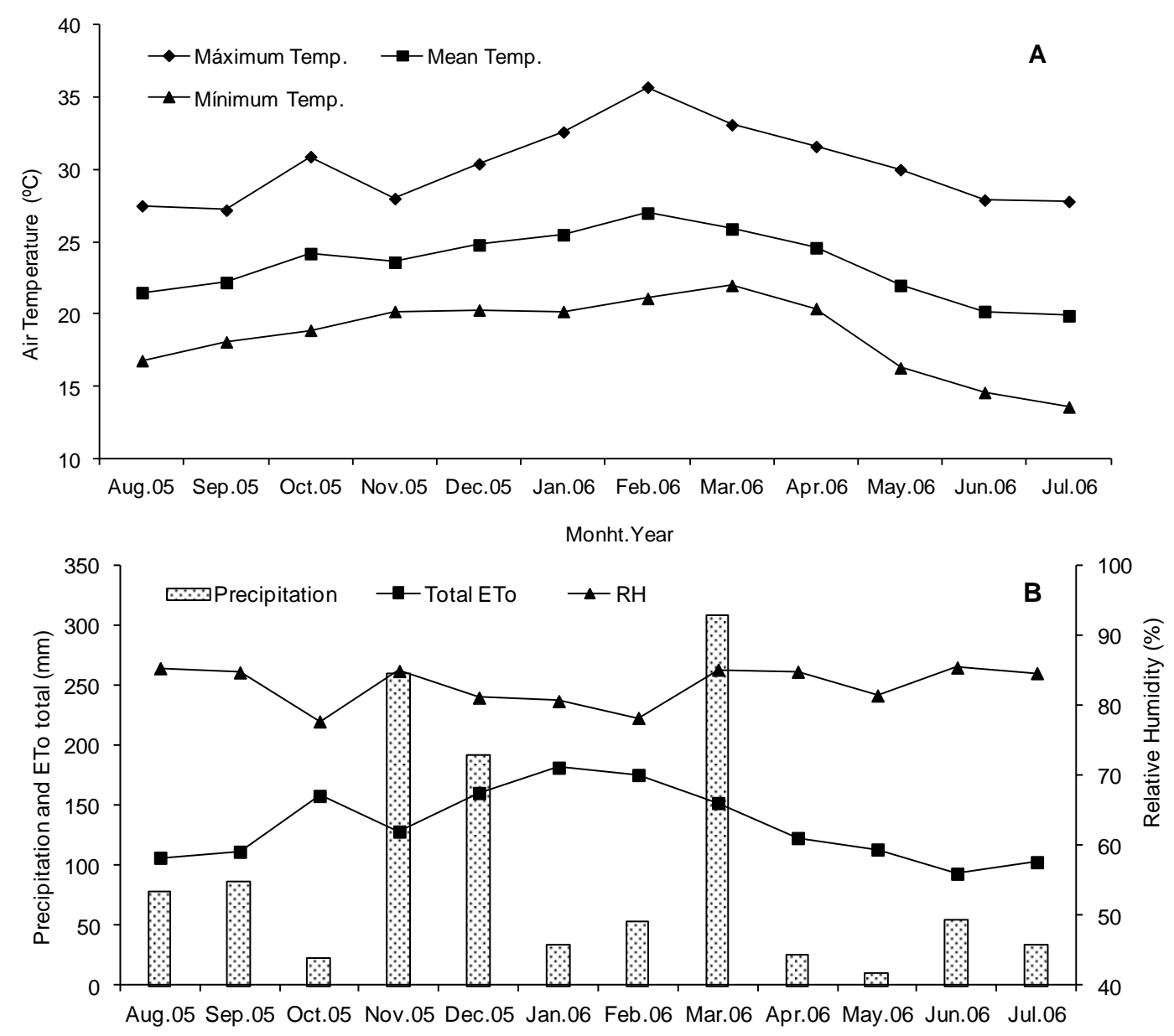

Monht.Year

Fig 1. Averages of the maximum, median and minimum air temperature at the studied sites (A) and the relative humidity, total evapotranspiration and total rainfall (B) recorded at the Meteorological Station of Sooretama, Espírito Santo, Brazil, which is located $40 \mathrm{~km}$ from the study sites. 
Table 2. Different physical properties of soil under conventional and organic coffee cultivation systems and from an Atlantic forest fragment at two soil depths. Jaguaré, Espírito Santo, Brazil.

\begin{tabular}{lcccccc}
\hline Area & $\begin{array}{c}\text { Depth } \\
(\mathrm{cm})\end{array}$ & $\begin{array}{c}\text { Den } \\
\mathrm{g} \mathrm{cm}^{-3}\end{array}$ & OHI & FC & PWP & WA \\
\hline CC & $0-10$ & 1.59 & 0.000 & 0.213 & 0.148 & 0.065 \\
SE & & 0.02 & 0.000 & 0.009 & 0.008 & 0.009 \\
CC & $10-20$ & 1.58 & 0.001 & 0.207 & 0.161 & 0.046 \\
SE & & 0.02 & 0.001 & 0.008 & 0.007 & 0.014 \\
\hline OC & $0-10$ & 1.40 & 0.042 & 0.233 & 0.168 & 0.065 \\
SE & & 0.04 & 0.011 & 0.010 & 0.006 & 0.014 \\
OC & $10-20$ & 1.50 & 0.024 & 0.227 & 0.153 & 0.073 \\
SE & & 0.01 & 0.014 & 0.007 & 0.011 & 0.006 \\
\hline AF & $0-10$ & 1.30 & 0.045 & 0.155 & 0.110 & 0.045 \\
SE & & 0.03 & 0.008 & 0.009 & 0.011 & 0.007 \\
AF & $10-20$ & 1.45 & 0.035 & 0.201 & 0.146 & 0.055 \\
SE & & 0.06 & 0.014 & 0.014 & 0.015 & 0.005 \\
\hline
\end{tabular}

Note: $\mathrm{Den}=$ density, $\mathrm{OHI}=$ optimal hydric interval, $\mathrm{FC}=$ field capacity, $\mathrm{PWP}=$ permanent wilting point and WA = water availability. $\mathrm{CC}-$ conventional conilon, $\mathrm{OC}-$ organic conilon, $\mathrm{AF}$ - Atlantic forest, $\mathrm{SE}$ - standard error.

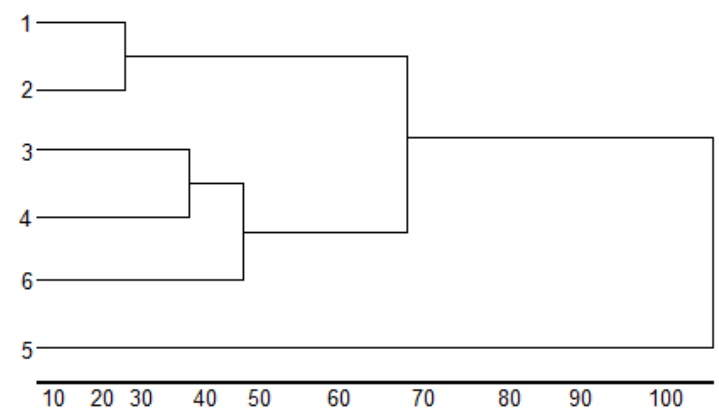

Fig 2. Divergence between the studied coffee management systems and Atlantic forest fragment characterised by determining the average Euclidian distance using the nearest-neighbour method based on the soil physical properties. Jaguaré, Espírito Santo, Brazil. Note: 1 . Conventional coffee soil at a depth of $0-10 \mathrm{~cm}$. 2. Conventional coffee soil at a depth of 10-20 cm. 3. Organic coffee soil at a depth of 0-10 cm. 4. Organic coffee soil at a depth of 10-20 cm. 5. Atlantic forest soil fragment at a depth of 0-10 cm. 6 . Atlantic forest soil fragment at a depth of $10-20 \mathrm{~cm}$.

C. canephora in the present study, especially for the coffee under conventional management. The relation between soil $\mathrm{RP}$ and soil moisture is not always linear because the relation is influenced by soil density (Valadão Junior et al., 2014). However, drier soil exhibits higher resistance.

The physical soil structure observed for the organic coffee management seems to be more sustainable than that of the conventional management. This difference may be associated with the lower use of machines and soil turning, in addition to other factors, because these processes result in soil compaction and degradation of soil physical properties (Fidalski et al., 2009). Another factor that may positively influence the soil physical properties is the higher concentration of organic matter (Table 1), because it indicates a complex system, with dynamics governed by the addition of organic materials of different nature and types and their continuous transformation through the action of biological, chemical and physical factors. This system influences cation retention, soil structural stability, water infiltration and retention, soil aeration, protection against microorganisms, and nutrient supply for plants (Graham et al., 2002).

\section{Soil optimal hydric interval}

Optimal hydric interval (OHI) was zero for the 0-10 cm-deep layer and $0.001 \mathrm{~cm}^{3} \mathrm{~cm}^{-3}$ for the $10-20 \mathrm{~cm}$-deep layer for the soil under conventional management (Table 2); these values are considered critical. Zero OHI values were also found by Torres et al. (2014) for soils under intensive grazing, thereby suggesting that the zero values are associated with compaction. Petean et al. (2011) also observed excessive grazing and trampling to result in pronounced $\mathrm{OHI}$ decreases. OHI was similar for the organic coffee plantation and the Atlantic forest soil (Table 2), thereby indicating that the organic cultivation system OHI was not affected.

\section{Soil water availability}

The water availability (WA) was similar for the two tested management systems and greater than that of the Atlantic forest fragment. This result is important because it enables better water use by coffee plants in periods of significant water deficits. Gontijo et al. (2008) studied the physicalhydric properties at different sampling positions and observed higher water availability at the coffee crown projection and inter-row areas when compared to the coffee traffic row and native forest.

\section{Soil porosity}

Atlantic forest exhibited higher total porosity (TP) and macroporosity and lower microporosity at both depths tested. This result is in agreement with that of Araujo-Junior et al. (2011), who studied areas cultivated with Arabica coffee under different weed management schemes. Also for Arabica coffee, Iori et al. (2014) observed higher soil density and soil $\mathrm{RP}$ and a decrease in total pore volume at the traffic row, which became more pronounced over time. The lowest TP and macroporosity were observed for the soil under conventional management (Fig. 4), for which at least three 


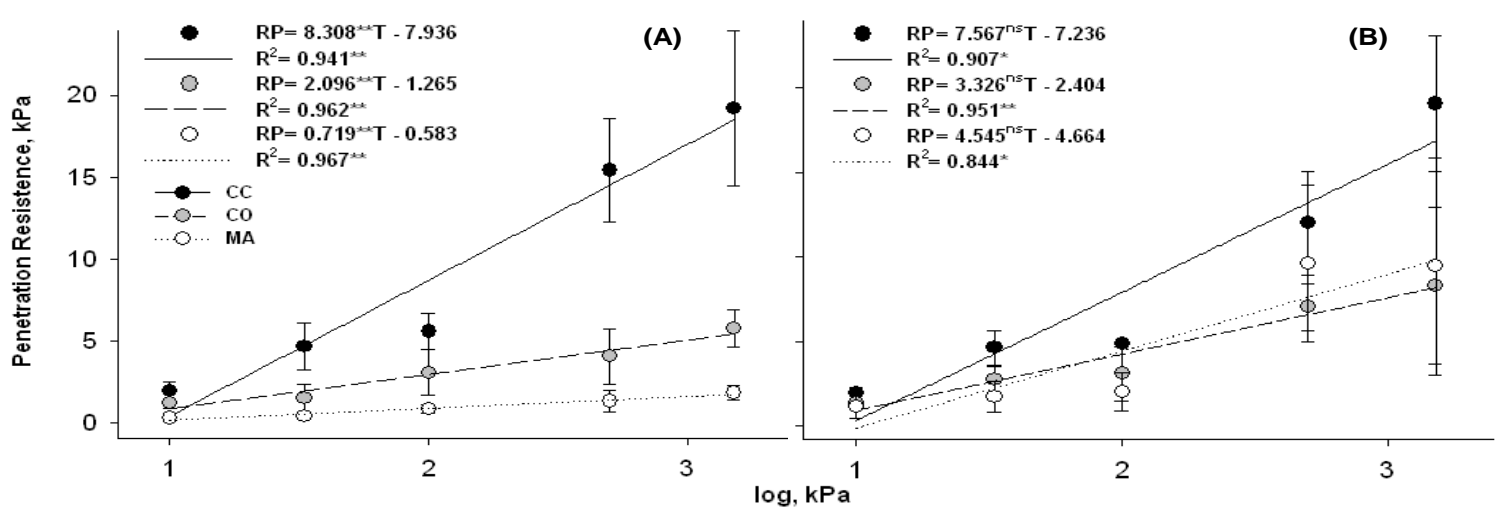

Fig 3. Soil RP for coffee under different types of management from depths of $0-10 \mathrm{~cm}$ (A) and $10-20 \mathrm{~cm}$ (B). CC - conventional Conilon coffee; OC - organic Conilon coffee; AF - Atlantic forest; T - pressure applied to soil; ${ }^{*}-$ significant at $p<0.05 ;{ }^{* *}-$ significant at $p<0.01,{ }^{\mathrm{ns}}-$ not significant.

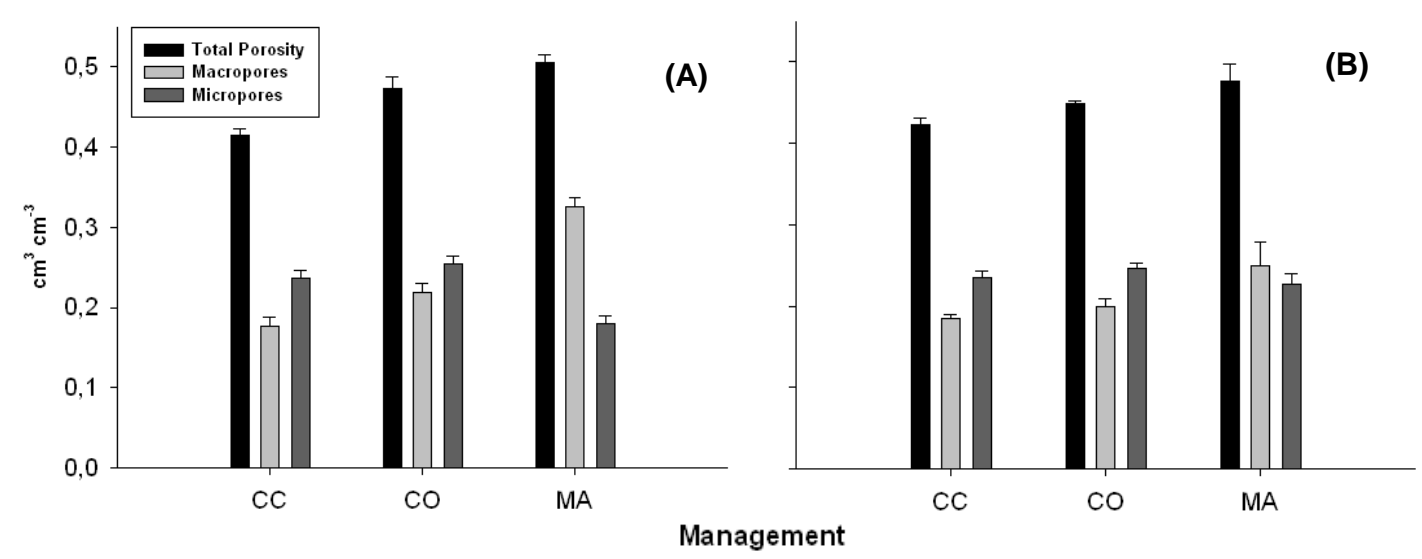

Fig 4. Total porosity, macropores and micropores for soil under different coffee crop management schemes at depths of 0-10 cm (A) and 10-20 cm (B). CC - conventional Conilon coffee; OC - organic Conilon coffee; AF - Atlantic forest.

tractor runs per year were performed. Cortez et al. (2014) reported that two tractor runs were sufficient to decrease porosity and increase compaction and soil mechanical RP. Gontijo et al. (2008) studied traffic at an Arabica coffee plantation and observed significant decreases in the TP and macroporosity and an increase in the microporosity for the traffic row and crown projection areas compared with the inter-row and native forest. Macropore decrease is due to the collapse of soil structure, which decreases the volume of larger pores, as a result of the excessive weight applied to the soil by machine operations. Occurrence of compaction may therefore deform soil aggregates, thus decreasing the volume of larger pores. The breaking of aggregates produces fragments that fill the macropores, thereby creating additional micropores. Sousa Neto et al. (2014) reported increased soil density and RP and decreased TP, macroporosity, and organic carbon in pastures when compared with native vegetation.

\section{Materials and Methods}

\section{Experiment location and climate conditions}

The experiment was conducted in the municipality of Jaguaré, State of Espírito Santo, Brazil, at latitude $18^{\circ} \mathrm{S}$ and longitude $40^{\circ} \mathrm{W}$ and an altitude of approximately $80 \mathrm{~m}$. Samplings were collected in July 2006. The region's climate is Aw tropical according to the Köppen climate classification, with hot and humid summers and dry winters. The average annual rainfall is $1,200 \mathrm{~mm}$. The average temperature is higher than $12{ }^{\circ} \mathrm{C}$ in colder months and lower than $34{ }^{\circ} \mathrm{C}$ in hotter months. Aspects of the climate data during the experimental period were similar to historical trends (Fig. 1).

\section{Organic and conventional management areas}

Two areas cultivated with Coffea canephora cv. Conilon (under organic and conventional management) and an Atlantic forest fragment, which was used as reference, were selected. The Atlantic forest fragment was subjected to burning 25 years before the beginning of the experiment and to the removal of large trees 15 years before. The organic coffee cultivation was certified since planting, according to Brazilian legislation (Brazil, 2003). The crop was eight years old, was established from cuttings using approximately 20,000 orthotropic cuttings $\mathrm{ha}^{-1}$, was drip irrigated, with a productivity of $50 \mathrm{bags} \mathrm{ha}^{-1}$ in 2005 and 2006. Lime was never applied to the soil. At planting, $30 \mathrm{~g}$ of rock dust per plant were applied as micronutrient source, and two tons of agro-silica were added when the crop was five years old. 
Every year, from planting until the crop was six years old, fertilisation was performed by adding 4 to $5 \mathrm{~kg}$ of composted cattle manure mixed with coffee straw per plant. Over the last few years, fertilisation with cow manure and liquid peat was performed twice a year. Plant health control was performed using specific liquid sprays, as permitted by the organic agriculture legislation (Brazil, 2003). Prior to coffee planting, the area was occupied by secondary forest. The coffee plantation under conventional management was nine years old, was established from cuttings using approximately 20,000 orthotropic cuttings $\mathrm{ha}^{-1}$, with a productivity of 60 bags ha ${ }^{-1}$ in 2005 and 2006. Two $\mathrm{tha}^{-1}$ of lime were applied when the plantation was four years old, and four litters of composted coffee straw were applied when it was six years old. A year before soil sampling, four applications of $150 \mathrm{~g}$ nitrogen, phosphorus and potassium $(25,5$ and $20 \%$, respectively), one manual and two herbicide's weeding, as well as a spraying with epoxiconazole and pyraclostrobin fungicide (applied using a tractor), were performed. The crop was drip irrigated, and whilst young, a rotary tiller was used for weeding. Prior to coffee planting, the area was occupied by secondary forest and pasture.

\section{Soil sampling and analysis}

The study areas were divided into four plots, each with approximately $5,000 \mathrm{~m}^{2}$ in area, constituting four replicates. Samples were collected from soil layers at depths of 0 to 10 $\mathrm{cm}$ and 10 to $20 \mathrm{~cm}$, from the crown projection area of coffee plants, and at areas of the Atlantic forest fragment that exhibited micro-relief conditions that were similar to those of the sampling points of the cultivated areas. Soil samples were collected using an auger. Composite soil samples were composed of 12 point samples and used for granulometry and organic matter analyses. For each area a representative point was defined for collection of non-deformed samples. Granulometry was analysed using a pipette, organic matter was analysed according to the wet oxidation method and calorimetry, and particle density was analysed using the method of volumetric flask with alcohol (Silva, 2009). Undeformed soil samples were collected using an Uhland auger and a mallet. Six samples were collected using $100 \mathrm{~mL}$ volumetric rings, and three samples using $300 \mathrm{~cm}^{3}$ volumetric rings. The samples were wrapped in aluminium foil, placed in plastic bags, and taken to the laboratory for preparation. The excess undeformed samples were removed such that the sample volume corresponded to the ring volume. The 300 $\mathrm{cm}^{3}$ undeformed samples were used for determination of hydraulic conductivity of saturated soil $\left(\mathrm{K}_{\mathrm{s}}\right)$ using a constant load permeameter and the Darcy equation (Equation 1):

$\mathrm{K}_{\mathrm{s}}=\frac{V w \cdot L}{A \cdot t(h+L)}$ (Equation 1)

where $V_{w}$ is the water volume over time $t, A$ is the area of the sample cross section, $L$ is the sample length, and $h$ is the pressure potential at the top of the sample. Four equilibrium points were obtained using porous filter plate funnels $(1,3,6$ and $10 \mathrm{kPa}$ ) (Grohmann, 1960), and four were obtained using Richards' pressure chambers $(33,100,500$ and $1500 \mathrm{kPa})$ (Klute, 1986). Because there were only six soil samples, two of the samples were used to obtain two equilibrium points. The water mass retained by the sample was calculated as the difference between the wet and dry mass, following drying in an oven at $105-110^{\circ} \mathrm{C}$ for $48 \mathrm{~h}$. Soil moisture $\left(\theta, \mathrm{cm}^{3} \mathrm{~cm}^{-3}\right)$ was calculated as the ratio between the water volume retained (the mass of water divided by water density, which was assumed to be $1 \mathrm{Mg} \mathrm{m}^{-3}$ ) and the sample volume, which corresponded to the ring volume. Soil resistance to penetration (RP) was determined by subjecting samples to pressures of $10,30,100,500$ and $1500 \mathrm{kPa}$ at equilibrium moment, aiming to maintain a gradient of moisture among samples. A universal testing machine (Instron 5582) was used, with automated data recording and penetration velocity adjusted to $10 \mathrm{~mm} \mathrm{~min}^{-1}$. Data analysis was performed using the logarithms of the results obtained to improve the visualisation of variations in RP. A metal cone with a semiangle of $30^{\circ}$, base diameter of $6.35 \mathrm{~mm}$ and area of $31.8 \mathrm{~mm}^{2}$ was fixed at the base of a charge cell with a force capacity of $1 \mathrm{kN}$. The RP was measured every second using the charge cell-metal cone set, and measurements were recorded using a microcomputer with an interface. The RP was measured as the force $(\mathrm{N})$, and the values were transformed to pressure (MPa) by dividing the force applied by the cone base area. The arithmetic average of the RP between soil depths of 10 and $40 \mathrm{~mm}$ was calculated and considered representative of the tested sample and pressure level. Following these measurements, the samples were placed in an oven for determination of the dry mass. The soil density ( $\rho$, in units of $\mathrm{kg} \mathrm{dm}^{-3}$ ) was calculated using Equation 2:

$\rho=\mathrm{DM} / \mathrm{RV}$ (Equation 2)

Where; $\mathrm{DM}=$ mass of soil dried in an oven $(\mathrm{kg})$ and $\mathrm{RV}=$ ring volume $\left(\mathrm{dm}^{3}\right)$. The total porosity (TP, as $\mathrm{m}^{3} \mathrm{~m}^{-3}$ ) was determined using the soil density and particle density values using Equation 3:

$\mathrm{TP}=1-\rho / \rho_{\mathrm{p}}($ Equation 3$)$

The water retention curve was calculated by correlating the moisture values $(\theta)$ and the respective pressures $(\tau)$, according to the van Genuchten (1980) model (Equation 4):

$\theta=\theta_{r}+\frac{\theta_{s}-\theta_{r}}{\left(1+(\alpha \tau)^{n}\right)^{m}}$ (Equation 4)

Where; $\theta_{\mathrm{r}}\left(\mathrm{dm}^{3} \mathrm{dm}^{-3}\right)$ is the residual water content; $\theta_{\mathrm{s}}\left(\mathrm{cm}^{3}\right.$ $\mathrm{cm}^{-3}$ ) is the saturated water content; $\tau(\mathrm{cm})$ is the soil water pressure; and $\alpha, \mathrm{m}$ and $\mathrm{n}$ are fitted parameters. The saturated water content $\left(\theta_{\mathrm{s}}\right)$ was considered to be an independent variable and assumed to correspond to the total porosity (TP) of each sample.

The RP curve was obtained by fitting the RP values to the $\theta$ (soil water content) and $\rho$ values, according to the model (Equation 5):

$\mathrm{RP}=\mathrm{a} \tau^{\mathrm{b}} \rho^{\mathrm{c}}$ (Equation 5)

Where; $\tau(\mathrm{kPa})$ is the soil water pressure; $\rho\left(\mathrm{kg} \mathrm{dm}^{-3}\right)$ is the soil density; and a, b, c, are fitted parameters. This model (Equation 5) is similar to the one proposed by Busscher (1990) but modified by replacing $\theta$ with $\tau$. This modification considerably increased the correlation between the observed and predicted RP values.The RP curve models were used to estimate the pressure values at which the RP became critical $\left(\tau_{\mathrm{RPC}}\right)$. This estimation was performed by iteration using the Microsoft Excel solver add-in, which yielded $2 \mathrm{MPa}$ as the critical RP. The samples that were previously subjected to 6 $\mathrm{kPa}$ of pressure were used for determination of microporosity (Grohmann, 1960). The TP was determined using the volumetric moisture of the saturated soil. Macroporosity was calculated as the difference between TP and microporosity. The permanent wilting point was determined as the moisture at critical RP of soil subjected to pressure of $1,500 \mathrm{kPa}\left(\theta_{\mathrm{RPC}}\right.$, which corresponds to a tension value $\tau_{\mathrm{RPC}}$ ). The critical soil moisture content for aeration $\left(\theta_{\mathrm{CA}}\right)$ was calculated by subtracting 0.1 from the TP values. The permanent wilting point $\left(\theta_{\mathrm{pwp}}\right)$ was calculated using the following equation: $\left[\mathrm{WA}=\theta_{\mathrm{cc}}(6 \mathrm{kPa})-\theta_{\text {pwp }}(1500 \mathrm{kPa})\right]$ (Oliveira et al., 2003). The optimal hydric interval $(\mathrm{OHI})$, in $\mathrm{m}^{3} \mathrm{~m}^{-3}$, was calculated as the difference between the higher $\left(\theta_{\mathrm{CC}}\right.$ or $\theta_{\mathrm{CA}}$, whichever 
was lowest) and lower critical moisture values $\left(\theta_{\mathrm{PWP}}\right.$ or $\theta_{\mathrm{RPC}}$, whichever was highest), according to Petean et al. (2011) and Torres et al. (2014).

\section{Statistical analysis}

The data were subjected to multivariate analysis (Cruz, 2001). The distance between treatments was estimated using the average Euclidean distance. Grouping was then performed using the nearest-neighbour method (complete linkage). The relative contribution of the parameters tested to the difference between treatments was estimated. A descriptive statistical analysis of the studied variables was performed through calculation of averages and standard errors.

\section{Conclusions}

Soil cultivated with Conilon coffee under organic management system resulted on high values of field capacity, permanent wilting point and water availability as compared to conventional management system.

The sum of better physical properties in soil under organic management provides this system a higher similarity to the Atlantic forest than the conventional system.

\section{Acknowledgements}

The authors wish to thank to Universidade Estadual do Norte Fluminense Darcy Ribeiro (UENF), Universidade Federal do Espírito Santo (UFES) and Conselho Nacional de Desenvolvimento Científico e Tecnológico (CNPq) for the structural support and Mr. Gerson Cosme and Casagrande's family for providing access to the studied plantations.

\section{References}

Araujo Junior CF, Dias Junior MS, Guimarães PTG, Alcântara EM (2011) Porous system and water retention capacity from oxisol under different management systems of invasive plants in coffee farming. Planta Daninha. 29(3):499-513.

Brasil (2003) Presidency of the Republic. Civil House Subdirection of Juridical Affairs. Law $\mathrm{n}^{\circ} 10831$ from December $23^{\text {th }}$, 2003. Rules over organic agriculture and provides further measures. Diário Oficial [da] República Federativa do Brasil, Poder Executivo, Brasília, DF, December $24^{\text {th }}, 2003$.

Busscher WJ (1990) Adjustment of flat-tipped penetrometer resistance data to a common water content. Trans Am Soc Agric Eng. 33(2):519-524.

Carneiro RG, Mendes IC, Lovato PE, Carvalho AM, Vivaldi LJ (2004) Biological indicators associated to phosphorus cycling in Cerrado soils under no-tillage and conventional planting. Pesq Agropec Bras. 39(7):661-669.

Castellini C, Bastianoni S, Granai C, Dal Bosco A, Brunetti M (2006) Sustainability of poultry production using the emergy approach: Comparison of conventional and organic rearing systems. Agric Ecosyst Env. 114:343-350.

Cortez JW, Olszevski N, Pimenta WA, Patrocínio Filho AP, Souza EB, Nagahama HJ (2014) Evaluation of tractor traffic intensity over some physical attributes of a yellow acrisol. R Bras Ci Solo. 38(3):1000-1010.

Costa EA, Goedert WJ, Sousa DMG (2006) Soil quality under no-tillage and conventional cropping system. Pesq Agropec Bras. 41(7):1185-1191.
Cruz, C. D. 2001. Software: Genes (Windows version): Computer software in genetics and statistics. Viçosa: UFV.

Evangelista CR, Partelli FL, Ferreira EPB, Pires FR (2013) Soil microbiological attributes in sugar-cane crop under organic and conventional management. Semina: Ci Agrár. 34(4):1549-1562.

Fagundes EAA, Silva TJA, Bonfim-Silva, E.M (2014) Initial development of sugar-cane varieties in oxisol under soil compaction levels. R Bras Eng Agríc Amb. 18(2):188-193.

Fidalski J, Barbosa GMC, Auler PAM, Pavan MA, Beraldo JMG (2009) Physical soil quality under preparation systems and dead mulch in orange orchards. Pesq Agropec Bras. 44(1):76-83.

Gontijo I, Dias Junior MS, Guimarães PTG, Araujo Junior CF (2008) Physical and hydraulic attributes of a cerrado's oxisol at different sample positions in coffee plantation. $\mathrm{R}$ Bras Ci Solo. 32(6):2227-2234.

Graham MH, Haynes RJ, Meyer JH (2002) Soil organic matter content and quality: effects of fertilizer applications, burning and trash retention on a long-term sugarcane experiment in South Africa. Soil Biol Biochem. 34:93-102.

Grohmann F (1960) Distribution and size of pores in three soil classes in the state of São Paulo. Bragantia. 19(21):319-328.

Iori P, Dias Junior MS, Ajayi AE, Guimarães PTG, Abreu Júnior AA (2014) Influence of field slope and coffee plantation age on the physical properties of a Red-Yellow Latosol. R Bras Ci Solo. 38(1):107-117.

Klute A (1986) Laboratory measurement of hydraulic conductivity of saturated soils. Madison, American Society of Agronomy; p.253-261. (Monograph, 9).

Letey J (1985) Relationship between soil physical properties and crop production. Adv Soil Sci. 1:277-294.

Lima CLR, Reinert DJ, Reichert JM, Suzuki LEAS (2010) Crop productivity and penetration resistance of a red acrisol under different management systems. Pesq Agropec Bras. 45(1):89-98.

Muñoz A, López-Piñeiro A, Ramírez M (2007) Soil quality attributes of conservation management regimes in a semiarid region of south western Spain. Soil Till Res. 95:255265.

Oliveira GC, Dias Júnior MS, Resck DVS, Curi N (2003) Structural modifications and compression behavior of a red oxisol dystrophic acrisol under different management and utilization systems. Pesq Agropec Bras. 38(2):291-299.

Oliveira PR, Centurion JF, Centurion MAPC, Franco HBJ, Pereira FS, Bárbaro Júnior LS, Rossetti CV (2012) Physical quality of a red oxisol planted with soybean under compaction and irrigation levels. $\mathrm{R}$ Bras $\mathrm{Ci}$ Solo. 36(2):587-597.

Partelli FL, Covre AM, Oliveira MG, Alexandre RS, Vitória EL, Silva MB (2014) Root system distribution and yield of 'Conilon' coffee propagated by seeds or cuttings. Pesq Agropec Bras. 49(5):349-355.

Partelli FL, Vieira HD, Ferreira EPB, Viana AP, Martins MA, Urquiaga S (2012) Chemical and microbiological soil characteristics under conventional and organic coffee production systems. Commun Soil Sci Plant Anal. 43(5):847-864.

Partelli FL, Vieira HD, Souza PM, Golynski A, Poncian NJ (2006). Social-economical profile of organic coffee growers in northern Espírito Santo state - satisfaction with the activity and reasons for joining certification. Rev. Ceres 53(305):55-64. 
Petean LP, Tormena CA, Alves SJ (2011) Optimal hydric interval of a red dystroferric oxisol under no-tillage planting in a system of husbandry-farming integration. $\mathrm{R}$ Bras Ci Solo. 34(5):1515-1526.

Reichert JM, Kaiser DR, Reinert DJ, Riquelme UFB (2009) Temporal variation of soil physical proprieties and root growth in beans under four management systems. Pesq Agropec Bras. 44(3):310-319.

Secco D, Reinert DJ, Reichert JM, Silva VR (2009) Physical attributes and grain yield of wheat, soybean and corn in two compacted and scarified oxisols. Ci. Rural. 39(1):58-64.

Silva FC (2009) Coordinator. Manual for chemical analysis of soils, plants and fertilizers. $2^{\text {nd }}$ ed. rev. Brasília, DF.

Silva, A.P. da; Kay, B.D.; Perfect, E. (1994) Characterization of the least limiting water range. Soil Science Society of America Journal, Madison, 58(6):1775-1781.

Sousa Neto EL, Andrioli I, Almeida RG, Macedo MCM, Lal R (2014) Physical quality of an oxisol under an integrated crop-livestock-forest system in the brazilian cerrado. $\mathrm{R}$ Bras Ci Solo. 38(2):608-618.
Torres LC, Barros KRM, Lima HV (2014) Modifications in physical quality of a yellow oxisol under pasture. Acta Amaz. 44(4):419-426.

Unger PW, Kaspar TC (1994) Soil compaction and root growth: a review. Agron J. 86(5):759-766.

Valadão Junior DD, Biachini A, Valadão FCA, Rosa RP (2014) Penetration resistance according to penetration rate, cone base size and different soil conditions. Bragantia. 73(2):171-177.

van Genuchten MT (1980) A closed form equation for predicting hydraulic conductivity of unsaturated soils. Soil Sci Soc Am J. 44(5):892-898. 